\title{
PERAN UANG DALAM PRODUKSI (Telaah Economic Value of Time sebagai Penunjang Faktor Produksi)
}

\author{
Agus Alimuddin'), Suhairi'2) \\ 1)Universitas Islam Indonesia Yogyakarta \\ 2)Institut Agama Islam Negeri Metro \\ agusalimuddin@gmail.com
}

\begin{abstract}
Money is a medium that stores value so as to change the purchasing power in the future and have a good stability, money has a role in the production process that aims to create goods or services to meet human needs So that the production process can be fulfilled and carried out according to planned objectives. Money as a support in maximizing the production factors, without the role of money then will experience slowness in the production process aknew even experience setbacks. Researchers use the review of the library with a descriptive-analysis method to display the analysis done, by trying to compare the problems studied with related Literaetur on the problem being observed, this study Analyzing the role of money in production (studying the economic value of time as supporting the production factor), production has the factors to be fulfilled namely, capital, natural resources, manpower, and production management, in meeting the factors Production often lacks producers in the fulfillment of factors in the production process, money becomes supporting that can help in fulfilling the needs by obtaining and using money in accordance with Islamic values and used To meet human needs.

Keywords: Factors of Production, Islamic Values, Money.
\end{abstract}

\begin{abstract}
Abstrak
Uang merupakan media yang menyimpan nilai sehingga dapat mengubah daya beli pada waktu yang akan datang dan memiliki stabilitas yang baik, uang mempunyai peran dalam proses produksi yang bertujuan menciptakan barang atau jasa untuk memenuhi kebutuhan manusia sehingga proses produksi dapat terpenuhi dan terlaksana sesuai dengan tujuan yang direncanakan. Uang sebagai penunjang dalam memaksimalkan faktor-faktor produksi, tanpa peran uang maka akan mengalami kelambatan dalam proses produksi atahu bahkan mengalami kemunduran. Peneliti menggunakan kajian pustaka dengan metode deskriptif-analisis dalam memaparkan analisis yang dilakukan, dengan mencoba membandingkan permasalahan yang ditelaah dengan literaetur yang berkaitan pada masalah yang sedang diamati, penelitian ini menganalisa peran uang dalam produksi (menelaah economic value of time sebagai penunjang faktor produksi), produksi memiliki faktorfaktor yang harus terpenuhi yakni, modal, sumber daya alam, tenaga kerja,
\end{abstract}


dan manajemen produksi, dalam memenuhi faktor produksi acap kali produsen mengalami kekurangan dalam pemenuhan faktor dalam proses produksi, uang menjadi penunjang yang dapat membantu dalam pemenuhan kebutuhan dengan cara mendapatkan dan menggunakan uang sesuai dengan nilai-nilai Islam dan digunakan secara maksimal agar dapat memenuhi kebutuhan manusia.

Kata Kunci: Faktor Produksi, Nilai-nilai Islam, Uang.

\section{A. Pendahuluan}

Kegiatan produksi sebagai tindakan dalam pemenuhan kebutuhan manusia, agar manusia dapat menjalankan aktivitas dalam kehidupannya sampai pada titik kesejahteraan, ${ }^{1}$ produksi sebagai suatu proses yang bertujuan untuk menciptakan produk ataupun jasa yang digunakan untuk memenuhi kebutuhan manusia sebagai konsumen, produksi sebagai proses dari barang dasar menjadi barang yang siap pakai. ${ }^{2}$

Produksi sebagai bagian dari mata rantai dari konsumsi dan distribusi maka dengan adanya produksi kebutuhan konsumen akan terpenuhi baik dalam bentuk barang atau jasa, jika kegiatan produksi berhenti maka akan berhenti kegiatan perekonomian. ${ }^{3}$ Produksi memiliki pengaruh yang besar dalam kehidupan manusia karena menempati sebagian penting dalam keberlangsungan hidup manusia jika dilihat dari tingkat dan taraf masing-masing. Maka hal yang berkaitan dengan kegiatan produksi melekat beberapa hal pokok yakni, barang yang diproduksi, proses produksi, dan diciptakan untuk siapa barang atau jasa itu diproduksi, ini bertujuan untuk menganalisa aktifitas produksi tersebut layak diciptakan. Kelayakan ini harus dilihat dari faktor pendukungnya yakni, tenaga kerja, modal, sumber daya alam, dan kecakapan tata laksana. ${ }^{4}$

Hadirnya uang mampu memudahkan kegiatan perekonomian dalam melakukan transaksi dibanding dengan sistem transaksi lain seperti barter dengan syarat yang begitu kompleks dan tidak sesuai dengan kebutuhan saat ini, kebutuhan manusia terkadang memiliki kesamaan sehingga memiliki kekurangan ketika melakukan transaksi dan penentuan penilaian pada sistem barter. Dengan hlm. 450 .

${ }^{1}$ Muhammad Baqir Al-Sadr, Iqtishaduna, (Bairut: Dar At-Ta'aruf Lil Mathbu'at, 1987),

2 Vina Sri Yuniarti, Ekonomi Mikro Syariah, (Bandung: Pustaka Setia, 2016), hlm. 121.

3 Jaribah Bin Ahmad Al-Haritsi, Fikih Ekonomi Umar Bin Khathab, (Jakarta Timur: Khalifa, 2006), hlm. 41.

${ }^{4}$ Nur Chamid, Jejak Langkah Sejarah Pemikiran Ekonomi Islam, (Yogyakarta: Pustaka Pelajar, 2010), hlm. 327. 
hadirnya uang sebagai barang atau benda yang disepakati untuk sarana mendapatkan benda atau barang lain, yang telah disepakati bahwa uang sebagai media yang bisa ditukarkan.

Uang memiliki peran penting dalam proses produksi, uang dalam kegunaannya sebagai alat tukar pada barang dan tenaga sebagai pengukur barang atau tenaga yang digunakan. Untuk memenuhi faktor-faktor produksi maka diperlukan uang sebagai perantara dalam pemenuhan kebutuhan. Hal ini dilakukan karena faktor produksi sangat diperlukan bendanya sebagai faktor kebutuhan produksi, sedangkan uang tidak bisa digunakan dalam memenuhi kebutuhan, tetapi dengan adanya uang dapat menjadi motif kemampuan daya beli yang terkandung dalam uang tersebut. 5

Dengan adanya uang mampu menjadi modal yang digunakan untuk mendapatkan faktor produksi seperti modal, tanah, tenaga kerja, serta kebutuhan produksi yang lain. Islam mengatur uang dengan seadil-adilnya dengan tidak membiarkan uang hanya dikuasai sebagian orang kaya, namun Islam mengatur uang dengan cara bekerja sama dengan akad mudharabah ataupun musyarakah, sehingga mendatangkan efisiensi dalam pemenuhan kebutuhan faktor-faktor produksi yang dibutuhkan sehingga dapat mendorong kegiatan produksi secara simultan yang akan meningkatkan tingkat produktifitas dalam proses produksi juga berdampak pada kemakmuran.

\section{B. Metode}

Metode merupakan cara pemecahan masalah yang ada pada penelitian, dengan adanya metode maka diharapakan dapat menghasilkan penelitian yang relevan. Metode merupakan hal yang harus ada dalam penelitian sebagai upaya yang dapat menguraikan permasalah yang akan diteliti oleh peneliti dengan menggunakan teknik tertentu sebagai penyesuaian dengan permasalahan yang diteliti agar dapat mencapai tujuan yang telah direncanakan. Peneliti penggunakan metode deskriptif-analisis dalam kajian pustaka ini, kajian pustaka merupakan teknik yang melihat permasalahan yang akan diteliti, lalu mencoba menganalisa dengan literatur yang sesuai dengan konsep penelitian juga tepat lalu

${ }^{5}$ Murthada Muthahari, Pandangan Islam Tentang Asuransi dan Riba, (Bandung: Pustaka Hidayah, 1995), hlm. 29. 
menghubungkan pemasalahan yang akan diteliti. Tujuan dari penelitian diharapkan dapat melahirkan konsep nilai-nilai yang menjadi landasaan dalam proses produksi sehingga dapat memenuhi kebutuhan manusia dengan baik dan tepat.

\section{Kajian Teoritik}

\section{Pegertian Uang}

Secara etimologi uang dalam pandangan ekonomi Islam berasal dari term al-naqdu-nuqud yang memiliki beberapa makna, term al-naqdu yakni memiliki arti yang baik dari dirham, menggenggaam dirham, sedangkan term al-naqdu memiliki arti tunai. Namun untuk term nuqud tidak memiliki arti dalam Al-Qur'an dan hadits karena masyarakat arab pada umumnya tidak memakai nuqud dalam menunjukkann harga. ${ }^{6}$ Dalam Al-Qur'an menggunakan kata dinar sebagai petunjuk mata uang yang berasal dari bahan emas, juga dirham sebagai petunjuk mata uang yang berasal dari perak. Selain term dinar dirham,juga menggunakan term wariq sebagai petunjuk pada dirham perak, sedangnkan term 'ain sebagai petunjuk pada dinar emas. ${ }^{7}$

Ibn Qayyim memandang bahwa dinar dirham yaitu nilai harga komoditas, artinya uang sebagai ukuran untuk menentukan nilai harga komoditas. ${ }^{8}$ Secara umum uang dapat didefinisikan sebagai alat tukar atau alat pengukur nilai yang diterbitkan oleh pemerintah Negara dalam bentuk kertas, emas, perak ataupun logam yang diterbitkan dalam bentuk serta gambar yang ditetapkan. ${ }^{9}$

Sahir Hasan,10 menjelaskan bahwa uang sebagai materi pengganti dalam kegiatan perekonomian, yakni sebagai media yang memiliki daya beli untuk melakukan transaksi guna memenuhi kebutuhan manusia. AlGhazali, dalam pandangannya menilai uang sebagai nikmat yang 2014), hlm. 279

${ }^{6}$ Rozalinda, Ekonomi islam Teori dan Aplikasinya pada Aktivitas Ekonomi, (Jakarta: Raja Grafindo,

7 Ahmad Hasan, Mata Uang Islami: Telaah Komprehensif Sistem Keuangan Islami, (Jakarta: Raja Grafindo Persada, 2005), hlm. 2.

8 Ibid., hlm. 5.

9 Ascarya, Akad dan Produk Bank Syariah, (Jakarta: Raja Grafindo Persada, 2008), hlm. 21.

10 Ahmad hasan, Mata.., hlm. 8. 
diberikan Allah SWT kepada masyarakat sebagai perantara atau mediasi yang berguna untuk memenuhi kebutuhan manusia, namun jika dilihat secara substansial uang tidak memiliki nilai, akan tetapi menjadi kebutuhan manusia dalam memenuhi seluruh kebutuhan manusia. ${ }^{11}$

Berdasarkan pendapat para ahli ekonomi Islam dalam mengartikan uang, maka dapat diartikan bahwa uang sebagai standar pengukur nilai, media yang digunakan sebagai alat tukar, dan juga alat pembayaran yang tertunda yang disepakati secara luas dan menyeluruh yang diterbitkan melalui aturan hukum sehingga uang dapat digunakan dalam menyelesaikan kebutuhan dan kewajiban.

\section{Fungsi Uang}

Uang mempunyai fungsi sebagai alat tukar antara barang dengan barang, juga berfungsi untuk menghindarkan perdagangan dengan cara sistem barter. Al-ghazali membahas fungsi uang dalam pandangan Islam secara rinci, yakni:

a. Standar Ukuran Nilai Harga (Qiwam Al-Dunya)

Uang yang berfungsi sebagai satuan nilai atau standar yang digunakan dalam kegiatan transaksi barang ataupun jasa, dalam fungsi yang cukup penting ini uang memiliki peran dalam menghargai barang ataupun jasa secara aktual, hadirnya uang memudahkan manusia dalam melakukan transaksi ekonomi di masyarakat. Al-Ghazali melihat uang seperti cermin, artinya uang mampu merefleksikan ukuran nilai harga pada benda yang dilihatnya. ${ }^{12}$

b. Media Transaksi (Hakim Mutawasith)

Uang sebagai media transaksi mampu memisahkan keputusan antara membeli atau menjual, dengan adanya uang yang digunakan sebagai alat tukar dapat menghilangkan kesamaan kebutuhan sebelum melakukan kegiatan transaksi. Apabila seseorang memiliki jagung atau gandum ketika membutuhkan lauk pauk sebagai kebutuhan pangan maka cukup dengan cara menjual jagung atau gandum tersebut dengan

11 Ahmad Dimyatu, Teori Keuangan Islam (Rekonstruksi Metodologis Terhadap Teori Keuangan alGhazali), (Yogyakarta: UII Press Yogyakarta, 2008), hlm. 59.

12 Adiwarman Azwar Karim, ekonomi Makro Islami, (Jakarta: Raja Grafindo Persada, 2007), hlm. 80 . 
menerima uang hasil dari pergantian barang tersebut, sehingga dapat memenuhi kebutuhan pangan seperti lauk dengan menggunakan media uang yang didapatkan dari hasil menjual jagung atau gandum tersebut.

c. Media Penyimpan Nilai (Al Mu'awwidlah)

Al-Ghazali mengatakan bahwa dibutuhkan harta yang mampu bertahan lama untuk keperluan yang dilakukan terus menerus maka disimpulkan harta yang mampu bertahan cukup lama berasal dari tambang, maka diciptakan uang yang berasal dari emas, perak, juga logam. ${ }^{13}$ Ketika uang menjadi media yang mampu menyimpan nilai maka uang bisa mengubah daya beli pada saat dan masa yang akan datang, dengan cara tidak mengeluarkan uang secara langsung dan seluruhnya pada satu waktu, tetapi bisa untuk disimpan dan digunakan untuk hari selanjutnya sesuai dengan keinginannya.

\section{Jenis Uang}

Uang yang berfungsi sebagai alat dalam kegiatan sehari-hari dalam melakukan transaksi yang diakui dan diterima oleh masyarakat, uang mempunyai sejarah evolusi yang cukup panjang dalam peradaban manusia sejak zaman primitif sampai saat ini,14 dalam perjalanan evolusi uang maka digolongkan dalam tiga jenis, yakni:

a. Uang komoditas

Uang komoditas atau yang biasa disebut uang barang, uang ini bisa digunakan dengan syarat barang tersebut memiliki nilai komoditas untuk digunakan sebagai kegiatan jual beli. Maka di masyarakat primitif dahulu dalam menjadikan barang yang memiliki nilai komoditas diberbagai wilayah berbeda antara satu wilayah dengan wilayah yang lain hal ini didasari dengan kondisi sosial dan ekonomi disetiap wilayah. 15

b. Uang logam

${ }^{13}$ Al-Ghazali, Ihya' Ulumuddin, (Beirut: Darul ma'rifah, 1993), hlm. 397.

${ }_{14}$ Abdul Aziz, Ekonomi Sufistik Model al-Gazali tentang Moneter dan Bisnis, (Jakarta: CV Wangsamerta), hlm. 51.

15 Mustafa Edwin Nasution, Pengenalan Ekslusif Ekonomi Islam, (Jakarta: Kencana Predana Media Group, 2006), hlm. 240. 
Fase ini merupakan kemajuan dalam sejarah uang. Penggunaan uang komoditas atau barang mendapatkan banyak kesulitan dalam melakukan transaksi proses perdagangan, sehingga beralih menggunakan uang logam. Orang romawi menggunakan logam yang terbuat dari tembaga dan perunggu untuk kegiatan jual beli, orang Yunani menggunakan logam yang terbuat dari besi.16 Uang logam memiliki jenis yang beragam, memiliki dua bentuk utama yakni sistem satu logam dan sistem dua jenis logam. Sistem satu logam hanya berlaku pada satu bentuk logam saja sehingga tidak akan berpengaruh jika ada mata uang bantu, sistem dua jenis logam mengadopsi dua macam logam yang terdiri dari logam emas dan perak yang keduanya menjadi mata uang yang utama. ${ }^{17}$

c. Uang kertas

Munculnya uang kertas pertama kali di China pada tahun 910 Masehi. Uang kertas digunakan pertama kali sebagai penopang dari uang logam emas dan perak, lalu pada 10 Masehi China tidak menjadikan uang kertas sebagai penopang uang logam emas dan perak lagi, pada abad 12 Masehi China sudah mengenal uang kertas yang tidak dijadikan atau ditukarkan lagi dengan emas ataupun perak. ${ }^{18}$

Namun ada kelemahan pada uang kertas yaitu tidak terjaminnya stabilitas nilai tukar dimasyarakat, tidak seperti uang emas atau perak yang memiliki nilai tukar cukup stabil, percetakan uang kertas yang berlebihan juga akan berdampak pada meningkatnya inflasi sehingga nilai pada mata uang mengalami penurunan dan meningkatnya harga barang di masyarakat. ${ }^{19}$ Pandangan Al-Ghazali bahwa uang kertas boleh saja digunakan meskipun terdapat banyak kelemahan dibandingkan uang yang berasal dari emas dan perak yang memiliki stabilitas cukup baik, negara wajib menjaga dan mengendalikan stabilitas nilai uang kertas dan menggunakan uang kertas sebagai alat

16 Ahmad Hasan, Mata.., hlm. 68.

17 Taqiyyuddin al-Nabani, Membangun Sistem Ekonomi Alternatif Perspektif Islam, (Surabaya: Risalah Gusti, 2009), hlm. 308.

18 Ahmad Hasan, Mata.., hlm. 76.

19 Rozalinda, Ekonomi.., hlm. 291. 
transaksi baik itu di dalam negeri juga dalam kegiatan transaksi ke luar negeri. ${ }^{20}$

\section{Produksi}

Produksi dapat diartikan sebagai suatu kegiatan yang memiliki tujuan untuk memberikan faedah pada suatu barang ataupun jasa, ada beberapa definisi produksi secara terminologi menurut para ahli ekonomi, banyak para ahli ekonomi yang tertarik membahas tentang produksi, diantaranya:

Kahf,,21 menjelaskan bahwa produksi dalam pandangan islam memiliki tujuan untuk memperbaiki diri manusia bukan hanya pada material tetapi juga moralitas manusia, hal ini sejalan dengan tujuan yang digariskan oleh Islam, bahwa manusia harus mendapatkan kebahagian dunia dan akhirat.

Muhammad Abdul Mannna, menjelaskan bahwa pentingnya untuk menekankan motif altuisme (altruism) bagi produsen islam sehinggan dalam melakukan sesuatu memiliki sikap kehati-hatian pareto optimaly dan given demand hypotesis yang dijadikan sebagai konsep fundamental dalam kegiatan produksi ekonomi konvensional.22

Ibnu Khaldun, mendefinisikan produksi sebagai pencurahan tenaga yang didedikasikan untuk melakukan kegiatan produksi yang bertujuan memenuhi kebutuhan manusia secara individu ataupun kelompok masyarakat.23 Muhammad Baqir Asshadr,24 dalam buku karyanya menjelaskan produksi sebagai suatu proses mengelola alam yang akan menciptakan suatu kebutuhan manusia yang berguna untuk kemaslahatan manusia. Imam Asy-Syatibi, ${ }^{25}$ juga berpendapat tentang produksi bahwa suatu proses yang memiliki tujuan untuk mendatangkan kemaslahatan manusia yang pada akhirnya untuk memelihara maqashid syari'ah yang terdiri lima unsur pokok yang dilindungi.

20 Taqiyyuddin al-Nabani, Membangun.., hlm. 302.

${ }^{21}$ Monzer Kahf, Ekonomi Islam: Telaah Analitik terhadap Fungsi Sistem Ekonomi Islam, (Yogyakarta: Pustaka Pelajar, 1997), hlm. 45.

${ }^{22}$ Muhammad Abdul Mannan, Islamic Economics; Theory and Practice, (Pakistan: Ashraf, 1983) hlm. 85.

${ }^{23}$ Abdurrahman Ibnu Khaldun, Muqaddimah Ibn Khaldun, (Beirut: Dar al-Fikr, tth), hlm. 380.

${ }^{24}$ Muhammad Baqir Ash Shadr, Iqtishaduna.., hlm. 643.

${ }^{25}$ Al-Syatibi, Al-Muwafaqat fi Ushul al-Syari"ah (Kairo: Mustafa Muhammad, tth), hlm. 347. 
Pemaparan dari beberapa definisi produksi menurut para ahli ekonomi diatas dapat ditarik kesimpulan bahwa produksi membuat perubahan pada suatu barang agar memiliki utilitas yang berguna bagi kebutuhan manusia, ${ }^{26}$ baik secara individu atau kelompok yang proses pelaksanaannya sesuai denga syari'at Islam. Produksi memiliki peranan penting dalam perekonomian hal ini dikarenakan produksi sebagai penentu kemandirian manusia, kemakmuran pada suatu bangsa dan kesejahteraan manusia. Ada beberapa ayat yang menjelaskan semua aktifitas produksi barang atau jasa yang dilakukan oleh setiap orang muslim untuk memperbaiki kehidupannya, diantara firmanNa yakni:

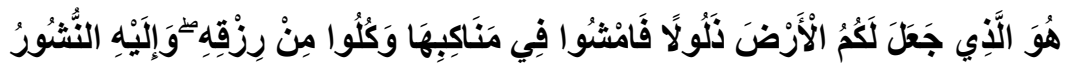

"Dialah yang menjadikan bumi itu mudah bagi kamu, Maka berjalanlah di segala penjurunya dan makanlah sebahagian dari rezki-Nya. Dan hanya kepada-Nya-lah kamu (kembali setelah) dibangkitkan." (QS. Al Mulk [67]: 15).27

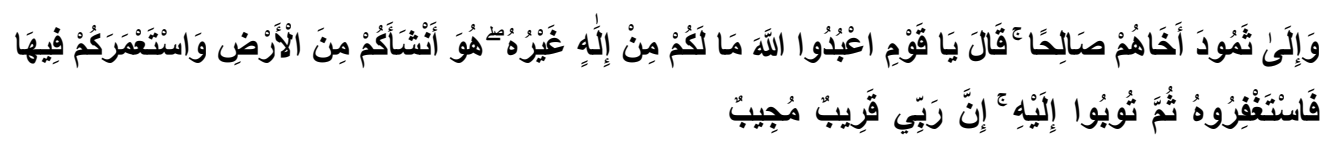

"Dan kepada Tsamud (kami utus) saudara mereka shaleh. Shaleh berkata: "Hai kaumku, sembahlah Allah, sekali-kali tidak ada bagimu Tuhan selain Dia. Dia telah menciptakan kamu dari bumi (tanah) dan menjadikan kamu pemakmurnya, karena itu mohonlah ampunan-Nya, kemudian bertobatlah kepada-Nya, Sesungguhnya Tuhanku Amat dekat (rahmat-Nya) lagi memperkenankan (doa hamba-Nya)." (QS. Hud[11]: 61).28

Dari ayat Al-Qur'an diatas bisa dapat disimpulkan bahwa dalam Islam bahwa produksi adalah segala bentuk yang dilakukan manusia dengan tujuan untuk mendatangkan kebermanfaatan dengan cara menjalajahi sumber ekonomi yang telah disediakan oleh Allah SWT, sehingga akan mendatangkan kemaslahatan bagi manusia.

${ }^{26}$ Muhammad, Prinsip-prinsip Ekonomi Islam, (Yogyakarta: Graha Ilmu, 2007), hlm. 80.

${ }^{27}$ Departemen Agama RI, Al-Qur'an dan Terjemahnya, (Bandung: Penerbit Diponegoro, 2005), hlm. 449.

${ }^{28}$ Ibid.., hlm. 182. 


\section{Prinsip Produksi}

Produksi memiliki prinsip dalam proses pelaksanaannya, prinsip produksi tidak akan pernah lepas dari syariat Islam sebagai aturan pelaksanaannya, produksi harus memilki kesesuaian dengan kebutuhan konsumsi manusia, konsumsi setiap manusia bertujuan untuk mencapai falah (kesejahteraan). Prinsip-prinsip dalam produksi diatur oleh Islam, yakni sebagai berikut:

Berproduksi dengan cara yang halal, hal ini menjadi kewajiban yang harus dilaksanakan bagi manusia dala proses produksi, namun tidak untuk produksi yang menganut ekonomi konvensional dalam prosesnya yang tidak mengenal istilah halam atau haram. ${ }^{29}$

Keadilan produksi, Islam telah mengatur keadilan dan keseimbangan dalam produksi dengan kemampuan yang dimiliki oleh manusia tanpa merugikan orang lain dalam produksinya. ${ }^{30}$

Produksi sesuai dengan kebutuhan, artinya produksi yang dilakukan harus memiliki kesamaan dengan tujuan Islam dalam menentukan kebijakan dalam produksi, karena produksi dapat menjauhkan manusia pada nilai-nilai religiusitas jika dalam menciptakan barang atau jasa jika dalam menentukan kebijakan tidak sejalan dengan nilai-nilai Islam. Untuk memenuhi kebutuhan konsumsi juga Islam melarang untuk berlebih-lebihan, dan telah mengatur skala prioritas dalam pemenuhan kebutuhan yakni dengan dharuriyyat, hajiyat, dan tahsiniyat. ${ }^{31}$

Produksi memperhatikan aspek sosial-kemasyarakatan, dengan merawat nilai-nilai keseimbangan yang ada di masyarakat, masyarakat mampu menikmati hasil dari produksi dengan layak dan kualitas yang baik.

\section{hlm. 117.}

${ }^{29}$ Yusuf Qardhawi, Norma dan Etika Ekonomi Islam, (Jakarta: Gema Insani Press, 1997),

30 A. Rahman I. Doi, Penjelasan Lengkap Hukum-hukum Allah (Syariah), (Jakarta: Raja Grafindo Persada, 2002), hlm. 188.

${ }^{31}$ Mawardi, Ekonomi Islam, (Pekanbaru: Alaf Riau: 2007), hlm. 67. 
Produksi yang optimal untuk memenuhi kebutuhan yang kompleks, 32 kegiatan ekonomi hadir bukan hanya didasarkan pada kelangkaan sumber daya dalam memenuhi kebutuhan manusia, akan tetapi timbul karena pengabaian sumber daya sehingga tidak optimal dalam mengelola segala anugerah yang telah diberikan Allas SWT.

\section{Tujuan Produksi}

Hakikat produksi berdiri atas tujuan yang akan dicapai, dalam kegiatan produksi seorang produsen mencoba mengoptimalkan faktor dalam produksi, sehingga akan menghasilkan suatu produk baik dalam bentuk barang ataupu jasa yang digunakan untuk memenuhi kebutuhan manusia. ${ }^{33}$ Umar bin Khatab melihat tujuan produksi dalam pandangan fiqh ekonomi, ${ }^{34}$ yaitu:

Memenuhi kebutuhan indivu dan keluarga, setiap manusia mempunyai kewajiban untuk meenuhi kebutuhannya baik secara individu maupun orang lain yang menjadi kewajibannya dengan melakukan aktivitas produksi. ${ }^{35}$

Tidak bergantung dengan orang lain, dalam Islam manusia hanya boleh bersandar kepada diri pribadi, dengan tidak mengharapkan apa yang dimiliki oleh orang lain. ${ }^{36}$

Menciptakan keuntungan yang optimal, setiap manusia untuk melakukan kegiatan produksi yang dapat menghasilkan keuntungan yang optimal dari kegiatan produksi yang dilakukan dengan cara yang baik dan benar. ${ }^{37}$

Mencari sumber-sumber ekonomi dan cara pemanfaatan, apa yang ada di muka bumi ini merupakan harta yang diberikan oleh Allah

32 Hendrie Anto, Pengantar Ekonomika Mikro Islami, (Yogyakarta: Jalasutra, 2003), hlm. 156.

33 Dwi Suwiknyo, Kompilasi Tafsir Ayat-Ayat Ekonomi Islam, (Yogyakarta: Pustaka Pelajar, 2010), hlm. 232.

${ }^{34}$ Jaribah bin Ahmad Al-Haritsi, Fikih.., hlm. 41.

${ }^{35}$ Lukman Hakim, Prinsip-prinsip Ekonomi Islam, (Jakarta: Penerbit Erlangga, 2012), hlm. 69.

36 Ibid.

37 Ibid. 
SWT yang ditujukan untuk memenuhi kebutuhan dan kebahagiaan manusia.

Melindungi harta dan memproduktifkan harta, harta harus dikembangkan dengan mengeksplorasi pada kegiatan-kegiatan produksi karena harta sebagai kemuliaan dan kehormatan dan juga mampu melindungi agama seseorang. ${ }^{38}$

Membebaskan dari belenggu ekonomi, setiap bangsa atau manusia yang mampu memproduksi kebutuhannya secara mandiri maka akan mencapai pada kemandirian dan terbebas dari belenggu ketergantungan pada bangsa atau manusia lainnya.

Taqarrub atas Allah SWT, kegiatan produksi memiliki tujuan untuk mendapatkan laba, menciptakan kemapanan, serta melindungi hartanya. Lebih daripada itu, manusia harus mempunya tujuan apa yang dilakukannya hanya untuk meraih pahala dari Allah SWT dari aktivitas yang dilakukannya agar menjadi pertolongan Allah SWT pada masa hidupnya. ${ }^{39}$

Tujuan dari produksi pada hakikatnya untuk mencapai kemaslahatan manusia di muka bumi demi terwujudnya falah (kesejahteraan) yang menjadi akhir dari kegiatan perekonomian dan tujuan manusia. Kegiataan produksi harus memperhatikan batasanbatasan dalam proses produksi agar menjaga harkat manusia agar mampu mengangkat derajat manusia, batasan-batasan produksi tidak boleh bertentangan dengan syariat Islam

\section{Faktor-faktor Produksi}

Kegiatan produksi tidak akan bisa berjalan dengan sendiri, produksi memerlukan variabel pendukung dalam merealisasikan barang atau jasa yang ingin diproduksi. Maka diperlukan variabel seperti, sumber daya alam, manajemen, tenaga kerja, modal, dsb. ${ }^{40}$ Maka produsen dalam menciptakan suatu produk dapat memahami variabel kebutuhan yang digunakan untuk menopang proses produksi

38 Jaribah bin Ahmad Al-Haritsi, Fikih.., hlm. 43.

${ }^{39}$ Lukman Hakim, Prinsip.., hlm. 69.

40 Suherman Rosyidi, Pengantar Teori Ekonomi Pendekatan kepada Teori Ekonomi Mikro dan Makro, (Jakarta: Raja Grafindo Persada, 2006), hlm. 55. 
agara dapat menghasilkan barang atau jasa sesuai tujuan yang diinginkan. ${ }^{41}$ Faktor produksi bersifat mutlak yang harus dijalankan dalam kegiatan produksi, ${ }^{42}$ ada berbagai macam faktor produksi, yakni:

a. Modal

Apapun yang menjadi penghasilan pendapatan selain tanah maka dapat dianggap sebagai modal termasuk aset yang digunakan dalam proses produksi. ${ }^{43}$ Modal dapat membantu untuk menambah kekayaan, Islam telah mengatur dengan seadil-adilnya dalam pengelolaan modal dengan melindung kepentingan orang miskin dan orang yang kekurangan modal dengan mengatur modal kerja sama antara orang yang membutuhkan dan yang memiliki kelebihan modal dengan menggunakan akad mudharabah (bagi hasil), musyarakah (kerjasama), dan mengeluarkan zakat, sehingga modal tidak hanya dikuasai oleh orang kaya saja. ${ }^{44}$ Modal di klarifikasikan menjadi dua bagian, pertama modal harta atau material yang memiliki fungsi untuk menambahkan tingkat produksi jika digunakan dalam proses produksi, kedua modal uang digunakan sebagai kebutuhan pembiayaan dalam proses produksi yang dilakukan. 45

b. Sumber daya alam

Merupakan bagian yang digunakan dalam proses produksi yang mencakup apa yang ada di bumi baik itu di atas bumi ataupun yang terkandung dalam bumi itu. Tanah sebagai material yang memiliki nilai ekonomi yang dapat membantu kebutuhan manusia yaitu tanaman, air, udara, cahaya, dan panas. ${ }^{46}$ Sumber daya alam terbagi menjadi dua. Pertama, sumber daya alam yang tidak dapat diperbaharui. Kedua, sumber daya alam yang terbarukan jika telah digunakan maka dapat dimanfaatkan kembali.

${ }^{41}$ Masyhuri, Ekonomi Mikro, (Malang: UIN Malang Press, 2007), hlm. 125.

${ }^{42}$ Sudarsono, Pengantar Ekonomi Mikro, (Jakarta: LP3ES, 1995), hlm. 120.

${ }^{43}$ Muhammad Djakfar, Etika Bisnis, (Jakarta: Penebar Plus, 2012), hlm. 124.

44 Rozalinda, Ekonomi.., hlm. 113.

45 Jaribah bin Ahmad Al-Haritsi, Fikih.., hlm 101.

${ }^{46}$ Rozalinda, Ekonomi.., hlm. 116. 
c. Tenaga kerja 47

Salah satu faktor produksi yang diakui oleh seluruh sistem ekonomi baik itu kapitalis, Sosialis, dan Islam. ${ }^{48}$ Pandangan Adam Smith, kerja merupakan faktor produksi yang berasal dari tenaga kerja manusia yang memproduksi barang menjadi barang dan jasa yang memiliki nilai yang bersumber dari kekayaan bangsa. ${ }^{49}$

d. Manajemen produksi

Merupakan ilmu yang mengatur seluruh proses yang dilakukan dalam mengelola sumber daya alam dan sumber daya lainnya agar dapat dimanfaatkan seefektif dan seefisen mungkin untuk dapat mencapai tujuan dari produksi. Maka manajer harus memiliki kemampuann dalam merencanakan, mengorganisir, mengordinasi, dan mengelola faktor produksi lainnya. 50

Empat faktor diatas merupakan hal yang harus ada dalam proses produksi, seluruh faktor dalam proses produksi faktor satu dengan yang lainnya harus saling bekerja sama. Apabila faktor-faktor produksi diatas dapat kita analogikan sebagai makhluk yang bernyawa dan berpikir, maka seluruh faktor, modal, sumber daya alam, tenaga kerja, dan manajemen produksi akan meminta untuk di balas seluruh jasa yang telah dikerjakan, modal seperti tanah, bangunan, mesin, maka akan dibayar atas sewa (rent) atau modal yang menggunakan uang dibayar melalui bunga atau bag hasil atas kerja sama, sumber daya alam yang dimanfaatkan maka membutuhkan uang untuk memperbaharui agar tetap dapat dimanfaatkan, tenaga kerja maka akan dibayar atas jasa yang dilakukan dengan gaji (salary), upah (wage), dan royalty, dan manajemen akan dibayar dengan uang atas pekerjaan yang dilakukan.

\section{Konsep Economic Value of Time}

Economic value of time merupakan teori yang dikembangkan pada abad ke-7 Masehi, pada saat masih digunakan emas dan perak sebaga

${ }^{47}$ Afzalur Rahman, Doktrin Ekonomi Islam, (Yogyakarta: PT. Dana Bhakti Wakaf, 1995), hlm. 227.

48 Soemitro, Pengantar Ekonomi dan ekonomi Pancasila, (Bandung: Eresco, 1983), hlm. 9.

${ }^{49}$ Carla Poli, Pengantar Ilmu Ekonomi, (Jakarta: Gramedia Utama, 1992), hlm. 6.

50 Suherman R, Sistem Ekonomi Islam, (Jakarta: Kencana, 2012), hlm. 207. 
alat tukar dalam kegiatan perekonomian. Lahirnya economic value of time merupakan gagasan dari ekonomi Islam untuk menegasikan teori dari ekonomi konvensional, penolakan ini didasarkan pada keadaan al kharaj bi la-dhaman (mendapatkan keuntungan tanpa mengeluarkan biaya atau modal), dan al-ghummu bi al-ghurni (mendapatkan keuntungan tanpa mempertimbangkan resiko). ${ }^{51}$

Economic value of time sebagai konsep yang menilai waktu yang mempunyai nilai ekonomi, Islam memandang setiap orang memilii waktu yang sama secara kuantitas, akan tetapi waktu setiap orang berbeda kuualitasnya. Maka nilai waktu setiap orang tergantung pada pemanfaatan secara pribadi, jika waktu digunakan seefektif dan seefien mungkin maka semakin tinggi nilai waktu seseorang.

Islam, memerintah umatnya untuk bukan sekadar mencari keuntungan hanya dari duniawi, tetapi mendapatkan keuntungan di akhirat dengan memanfaatkan waktu dengan efisien dan efektif. Time value of money tidak diperbolehkan dalam Islam, karena dalam konsep ini maka keuntungan yang didapatkan adalah bunga, sedangkan economic value of time menggunakan dasar penghitungan dengan nisbah atau margin. Sehingga economic value of time memiliki nilai keadilan dalam akad pembiayaan dengan bagi hasil (profit sharing), maka akan berdampak pada besaran nisbah yang menjadi kontrak antara kedua pihak yang bekerjasama.

\section{Pembahasan}

\section{Implementasi Peran Uang dalam Produksi}

\section{Modal}

Faktor produksi ini memang tidak sepenuhnya menggunakan uang dalam proses produksi, untuk memenuhi kebutuhan modal seperti tanah, bangunan gedung, serta aset yang lainnya terkadang produsen tidak seluruh yang dibutuhkan dapat terpenuhi. Uang dapat menjadi penopang dalam

51 Adiwarman Azwar Karim, Bank Islam: Analisis fiqih dan Keuangan, (Jakarta: Raja Grafindo Persada, 2004), hlm. 333. 
pemenuhan modal dengan cara yang sesuai dengan nilai-nilai Islam, produsen bisa melakukan kerja sama dengan orang lain yang memiliki surplus uang dengan menggunakan akad bagi hasil (mudharabah) lalu membagi keuntungan atau nisbah dari hasil produksi sesuai kesepakatan kedua pihak (shahibul maalmudharib) yang bekerjasama, jika produsen memiliki modal tetapi tidak sepenuhnya dapat memenuhi kebutuhan proses produksi dapat melakukan perkongsian atau bersekutu dengan pemilik modal lainnya dengan menggunakan akad kerja sama (musyarakah) kedua pihak atau bahkan lebih dapat bekerja sama dengan mencampurkan modal dan pekerjaan proses produksi dapat dilakukan bersama-sama oleh semua pihak yang bersekutu atau berkongsi dengan ketentuan diawal keuntungan dibagi secara proporsional sesuai kesepakatan, apabila mengalami kerugian maka risiko ditanggung bersama.

\section{Sumber Daya Alam}

Sebagai faktor produksi yang memanfaatkan apa yang ada di alam sebagai bahan dasar dalam proses produksi, sumber daya alam menjadi faktor pendukung proses produksi yang bertujuan untuk memenuhi kebutuhan manusia yang semakin hari semakin kompleks kebutuhan yang diperlukan, sumber daya alam terbagi menjadi dua, sumber daya alam yang terbarukan, ada yang proses terbarukannya secepat manusia dalam menggunakannya, sumber daya ini tidak akan hancur dan dapat di daur ulang, untuk dapat digunakan kembali maka diperlukan kesadaran penggunaan dengan cara berkelanjutan maka dalam penggunaannya dapat sesuai dengan kebutuhan yang diperlukan saat ini dan mempertahankan sumber daya alam yang ada untuk generasi yang akan datang. Permintaan konsumen yang terus meningkat acap kali membuat produsen lupa akan batasan penggunaan 
sumber daya yang ada dengan kewajaran seharusnya, maka produsen dapat membantu kecepatan daur ulang sumber daya alam agar dapat memenuhi permintaan konsumen dengan tidak mereduksi sumber daya alam yang tersedia, maka diperlukan peran uang sebagai penunjang produsen dalam membantu kecepatan daur ulang sumber daya alam yang terbarukan.

Sama halnya dengan sumber daya alam yang tidak terbarukan, produsen dapat meminimalisir penggunaan sumber daya tak terbarukan, sumber daya tak terbarukan membutuhkan waktu ratusan tahun untuk dapat menghasilkan sumber daya yang sama. Sumber daya tak terbarukan dihasilkan dari pengendapan ratusan tahun lalu yang dapat dinikmati sekarang, dan memiliki jumlah yang terbatas sehingga sumber daya ini tidak sepenuhnya dapat menjadi bahan dasar dalam proses produksi, maka produsen dapat menciptakan bahan pengganti dari bahan dasar yang digunakan agar kegiatan produksi bisa berkelanjutan tidak mengalami kekurangan bahan dasar yang akan mengakibatkan tidak terpenuhinya kebutuhan konsumen

\section{Tenaga Kerja}

Sebagai faktor penggerak dari faktor yang lainnya sehingga dalam produksi apapun tenaga kerja sangat diperlukan dan diakui semua sistem perekonomin. Tenaga kerja berasal dari manusia yang melakukan proses produksi barang atau jasa yang dilakukan, karena tidak mungkin proses produksi dapat berjalan sendiri mulai dari bahan dasar sampai barang yang siap untuk digunakan oleh konsumen. Islam mengatur dengan adil tentang hak manusia yang telah melakukan pekerjaan yang bermanfaat, berdasarkan ayat pada Al-Qur'an dan Hadits berikut:

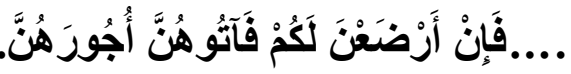


"...Kemudian jika mereka menyusukan (anak-anak)mu untukmu maka berikanlah kepada mereka upahnya..." (QS. Ath Thalaq[65]: 6).52

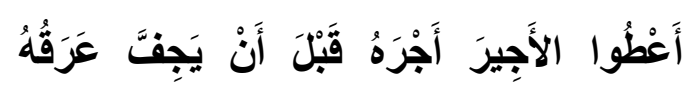

"Berikan kepada seorang pekerja upahnya sebelum keringatnya kering." (HR. Ibnu Majah, shahih).

Ayat Al-Qur'an dan Hadits diatas dapat diartikan dalam konteks produksi bahwa pada setiap manusia yang menjadi tenaga kerja dan telah melakukan pekerjaan berhak mendapatkan upah, gaji, atau royalty yang diberikan kepada manusia dari pekerjaan yang telah dilakukan sebagai bentuk penghargaan yang diberikan oleh produsen. Uang dapat dijadikan bentuk pembayaran yang digunakan produsen dalam memberikan upah atau gaji.

\section{Manajemen Produksi}

Manajemen memerlukan seseorang yang memiliki kemampuan yang baik dalam merencanakan sampai pada proses akhir, maka tidak semua orang dapat menjadi manajer yang mengatur seluruh kegiatan produksi, manajemen produksi membutuhkan kemampuan yang cukup agar proses produksi dapat berjalan dengan baik dan mencapai tujuan dari produksi. Sehingga pemberian gaji kepada manajer dihargai lebih tinggi dibandingkan dengan pekerja yang lain, hal ini sebagai bentuk adil dari kemampuan yang dimiliki dalam mengelola perusahaan produksi barang atau jasa. Maka dibutuhkan dengan kemampuan yang baik, berbanding lurus dengan gaji yang didapatkan.

\section{E. Kesimpulan}

Produksi menjadi mata rantai yang cukup penting dalam memenuhi kebutuhan konsumsi manusia dalam keberlangsungan kehidupan, terciptanya barang atau jasa tidak secara tiba-tiba terwujud dari proses produksi yang singkat, produksi memerlukan faktor-faktor yang menopang agar terwujudnya barang atau jasa yang ingin diciptakan. Faktor produksi harus terpenuhi secara lengkap dan saling berkaitan

52 Departemen Agama RI, Al-Qur'an.., hlm. 446. 
antara satu faktor dengan faktor yang lainnya, dan uang memeliki peran sebagai pendukung dalam memenuhi faktor-faktor produksi.

Islam mengenal economic value of time dalam penggunaan uang, maka uang bisa didapatkan dan dimanfaatkan dengan cara yang sesuai syariat Islam dalam penggunaannya. Namun tidak sepenuhnya uang menjadi faktor yang utama dalam proses produksi, uang hanya menjadi pendukung atas kekurangan dalam mewujudkan barang atau jasa dari proses produksi. 


\section{DAFTAR PUSTAKA}

Al-Ghazali. 1993. Ihya' Ulumuddin. Beirut: Darul ma'rifah.

Al-Haritsi, Jaribah Bin Ahmad. 2006. Fikih Ekonomi Umar Bin Khathab. Jakarta Timur.

Al-Nabani, Taqiyyuddi. 2009. Membangun Sistem Ekonomi Alternatif Perspektif Islam. Surabaya: Risalah Gusti.

Al-Sadr, Muhammad Baqir. 1987. Iqtishaduna. Bairut: Dar At-Ta'aruf Lil Mathbu'at.

Al-Syatibi. Tth. Al-Muwafaqat fi Ushul al-Syari'ah. Kairo: Mustafa Muhammad.

Anto, Hendrie. 2003. Pengantar Ekonomika Mikro Islami. Yogyakarta: Jalasutra.

Ascarya. 2008. Akad dan Produk Bank Syariah. Jakarta: Raja Grafindo Persada.

Aziz, Abdul. tth. Ekonomi Sufistik Model al-Gazali tentang Moneter dan Bisnis. Jakarta: CV Wangsamerta.

Chamid, Nur. 2010. Jejak Langkah Sejarah Pemikiran Ekonomi Islam. Yogyakarta: Pustaka Pelajar.

Dimyatu, Ahmad. 2008. Teori Keuangan Islam (Rekonstruksi Metodologis Terhadap Teori Keuangan al-Ghazali). Yogyakarta: UII Press Yogyakarta.

Djakfar, Muhammad. 2012. Etika Bisnis. Jakarta: Penebar Plus.

Doi, A. Rahman I. 2002. Penjelasan Lengkap Hukum-hukum Allah (Syariah). Jakarta: Raja Grafindo Persada.

Hakim, Lukman. 2012. Prinsip-prinsip Ekonomi Islam. Jakarta: Penerbit Erlangga.

Hasan, Ahmad. 2005. Mata Uang Islami: Telaah Komprehensif Sistem Keuangan Islami. Jakarta: Raja Grafindo Persada.

Kahf, Monzer. 1997. Ekonomi Islam: Telaah Analitik terhadap Fungsi Sistem Ekonomi Islam. Yogyakarta: Pustaka Pelajar.

Karim, Adiwarman Azwar. 2004. Bank Islam: Analisis fiqih dan Keuangan. Jakarta: Raja Grafindo Persada.

2007. Ekonomi Makro Islami. Jakarta: Raja Grafindo Persada.

Khaldun, Abdurrahman Ibnu. tth. Muqaddimah Ibn Khaldun. Beirut: Dar al-Fikr.

Mannan, Muhammad Abdul. 1983. Islamic Economics; Theory and Practice. Pakistan: Ashraf.

Masyhuri. 2007. Ekonomi Mikro. Malang: UIN Malang Press.

Mawardi. 2007. Ekonomi Islam. Pekanbaru: Alaf Riau.

Muhammad. 2007. Prinsip-prinsip Ekonomi Islam. Yogyakarta: Graha Ilmu.

Muthahari, Murthada. 1995. Pandangan Islam Tentang Asuransi dan Riba. Bandung: Pustaka Hidayah. 
Nasution, Mustafa Edwin. 2006. Pengenalan Ekslusif Ekonomi Islam. Jakarta: Kencana Predana Media Group.

Poli, Carla. 1992. Pengantar Ilmu Ekonomi. Jakarta: Gramedia Utama.

Qardhawi, Yusuf. 1997. Norma dan Etika Ekonomi Islam. Jakarta: Gema Insani Press.

Rahman, Afzalur. 1995. Doktrin Ekonomi Islam. Yogyakarta: PT. Dana Bhakti Wakaf.

RI, Departemen Agama. 2005. Al-Qur'an dan Terjemahnya. Bandung: Penerbit Diponegoro.

Rosyidi, Suherman. 2006. Pengantar Teori Ekonomi Pendekatan kepada Teori Ekonomi Mikro dan Makro. Jakarta: Raja Grafindo Persada.

Rozalinda. 2014. Ekonomi islam Teori dan Aplikasinya pada Aktivitas Ekonomi. Jakarta: Raja Grafindo.

Soemitro. 1983. Pengantar Ekonomi dan ekonomi Pancasila. Bandung: Eresco.

Sudarsono. 1995. Pengantar Ekonomi Mikro. Jakarta: LP3ES.

Suherman R. 2012. Sistem Ekonomi Islam. Jakarta: Kencana.

Suwiknyo, Dwi. 2010. Kompilasi Tafsir Ayat-Ayat Ekonomi Islam. Yogyakarta: Pustaka Pelajar.

Yuniarti, Vina Sri. 2016. Ekonomi Mikro Syariah. Bandung: Pustaka Setia. 
92 | Agus Alimuddin, Suhairi

Halaman Ini Tidak Sengaja Untuk Dikosongkan 